\title{
Review
}

\section{Rancière's sentiments}

\author{
Davide Panagia
}

Duke University Press, 2018, vii-142 pp., ISBN: 978-0822370222

Contemporary Political Theory (2020) 19, 28-32. https://doi.org/10.1057/s41296-0180263-y; Published online 11 September 2018

Jacques Rancière's wide-ranging and difficult to categorize work has recently gained increasing attention in English-speaking political theory. Davide Panagia's Rancière's Sentiments is a unique and exciting contribution to this vibrant literature. Panagia's work is unique in two respects. First, it specifically focuses on the relationship between aesthetics and politics in Rancière's oeuvre. Second, rather than trying to explain or contextualize Rancière's work, Panagia chooses to put on display what he identifies as Rancière's distinctive mode of reading and writing: his 'sentimental mode' (p. 36). Accordingly, Panagia's book seeks to challenge extant sensibilities and perceptibilities, and open up new possibilities of thinking, seeing, and doing, by, among others, 'position[ing] things that typically don't belong together alongside (rather than against) one another' (p. 12). The result is a dense and absorbing volume that positions Jean-Jacques Rousseau's Second Discourse, Aristotle's Poetics and Metaphysics, Gustave Flaubert's Madame Bovary, and the debates that took place in the pages of the journal Cahiers du Cinéma in the 1950s, alongside Rancière's writings, including those that have largely been overlooked by political theorists, such as Film Fables, The Future of the Image, Politics of Literature, and, most significantly, Aisthesis. Through his juxtaposition of these seemingly disparate works and Rancière's oeuvre, Panagia not only offers a forceful and provocative reading of Rancière but also presents a compelling, if disorienting, account of what it means to practice political theory without being 'committed to the prescription of concepts, ideas, and norms for the purpose of a political program' (p. 5).

Rancière's Sentiments begins with an engaging preface that sets Rancière's thinking about aesthetics and politics against various forms of 'judgment-oriented political theory' (p. x). According to Panagia, politics of judgement, even in its most astute accounts, such as that of Linda Zerilli, rests on a pre-political 'commitment to the authority of responsiveness that compels one to have to provide reasons about one's forms of perceptibility and sensibility' (p. xii). In contrast to this view of politics, which calls upon the subject to 'elicit criteria for counting', Rancière's politics is 'about the making count' (p. xi), where political subjects

(c) 2018 Springer Nature Limited. 1470-8914 Contemporary Political Theory Vol. 19, 1, 28-32 
emerge as they take part in activities that do not belong to them, altering the configuration of the sensible that rendered them invisible and inaudible erstwhile. Accordingly, Panagia argues, Rancière moves away from 'a critical method that elaborates reasons for judgment, and the conditions for their implementation,' and instead adopts a 'scenographic critical disposition committed to arrangement and rearrangement of participatory forms' (p. xii). The rest of the book is devoted to displaying the workings of this critical disposition characterized by the simultaneity of aesthetics and politics.

The introduction presents an image of Rancière as a 'sentimental thinker' who 'believes that one's sensibilities and perceptibilities play a leading role in one's disposition to the world and to others, and that the work of politics is the work of arranging and adapting, if not transforming altogether, word-making sensibilities and perceptibilities' (p. 1). Throughout his oeuvre, Rancière affirms that politics is about altering the existing configurations of the sensible while simultaneously refusing to claim a position of authority on the basis of epistemic privilege. Thus, his works do not provide explanations; nor do they aim to reach the goal of intelligibility or offer prescriptions. Instead, and this is his 'manner of impropriety' (p. 7), like the aesthetic regime that displaced the representative logic in arts, he eschews purposiveness and offers his readers scenes that stage transformations of sensibilities and operations of undoing the structures of necessity. In this regard, Panagia insists, Rancière's writings are political and aesthetic at the same time.

The remaining chapters operate not unlike the scenes in Aisthesis; that is to say, rather than trying to illustrate or explicate an idea or a concept, Panagia's chapters show Rancière's thought, to use Rancière's own words for a different purpose, 'busy weaving together perceptions, affects, names, and ideas' (Rancière, 2014, p. xi). The first chapter explores Rancière's account of social and political change through an illuminating discussion of the notion of partager as 'his theory of radical mediation' (p. 29). Meaning both sharing and dividing in French, partager refers to both a dividing line between the sensible and the insensible and a point of contact between commonality and divisiveness. In this sense, each particular partition of the sensible (le partage $d u$ sensible) carries within it the possibility of 'a political partaking by elements excluded from [it]' (p. 31). Politics occurs when these elements disrupt (partagent) the existing order, 'thereby mediating the scene of contest and rearranging the conditions of perceptibility' (p. 33). This aspect of partager makes it a both political and aesthetic practice that finds resonances in Rancière's work as it too 'enacts radical forms of mediation that transform the existing divisions of any aestheticpolitical arrangement' (p. 23).

In his second chapter, Panagia reads Aristotle's Poetics along with his Metaphysics to delineate his formal system of representation as an archetype of an arrangement of sensibility that produces a notion of 'good fit,' forming a link 
between proper action and good sense. According to Panagia, this account of right disposition of actions is what Rancière means by the term decorum and 'decorum is the sensibility of the police' (p. 42). For, in Rancière's work, rather than being an apparatus of power, the police refers to a 'regulatory principle of distribution of sense and sensibility' (p. 51). This connection between police and decorum enables Panagia to conclude that the aesthetic regime of art, which emerges in 18th century of popular revolutions and thwarts the representative logic grounded in Aristotelian mimesis, also disrupts 'the political regime of representation that expects political action to fit the genre of epic' (p. 55). The rest of the chapter further explores this convergence of aesthetics and politics in debates on the cinematic technique of jump-cut montage, which, at least in Godard's work, not only disrupts expectations of narrative coherence but also invents 'a disjunctive relation between different shots' (p. 57). For Panagia, by eschewing the standards of narrative order stipulated by the representative logic, jump-cut editing embodies a philosophical and political claim that 'denies the existence of necessary relations' (p. 57).

With chapter three, Panagia turns his attention to Rancière's style, and most significantly, to his adoption of style indirect libre (free indirect discourse). The chapter engages with Flaubert's Madame Bovary, and its initial reception in France, to provide a fascinating account of style indirect libre as a radically egalitarian style that displaces authorial voice, making it impossible to distinguish the narrator, character, and author. This indeterminacy, which makes Flaubert and his style so central to Rancière's work, democratizes prose, 'making it so that no one stature, status, qualification, or intelligence is necessary for accessing the work' (p. 80).

The final chapter of the book, along with the conclusion, takes the reader back to the issue of political judgment. According to Panagia, to discard the model of judgment so prominent in political thinking, Rancière abandons purposive social science and replaces it with an aesthetic and literary style pointing to the democratic significance of 'unpurposivenes, indistinction, and reverie' (p. 93). What Panagia calls 'Rancière's democratic realism,' (p. 93) - just like the aesthetic regime of art, which relieved artistic production from the expectations of cause and effect - moves beyond thinking in terms of means and ends. Instead, it affirms 'the amorphous domain of the farniente of reverie-where people and things do nothing' (p. 87) for democratic politics. For indeed, Panagia argues, it is 'in those moments of do-nothing-ness that we uncover new worlds and novel forms of participation dissident from common sense of decorum' (p. 98).

As a book that adopts Rancière's contrarian and polemical sensibility, Rancière's Sentiments raises many interesting questions. Given the space that I have, I will focus on only two. For Panagia, his most controversial claim is that 'Rancière is not a theorist of political judgment' ( $p$. viii). In light of the compelling reading that Panagia offers, it is difficult to challenge this claim insofar as it refers to Rancière's refusal to engage in a kind of political thinking that sets itself the goal 
of determining normative criteria with which to judge political acts and/or articulate the conditions of implementation of such criteria. What remains controversial, I believe, is Panagia's contention that for Rancière, the pronouncement of any form of judgment cannot but breed inequality, since it 'presumes a system of criteria for participation in the scene of judgment's locution' (p. viii). This contention leads him to conclude that Rancière 'privileges the activity of partaking (i.e. partager) over the activity of judging' (p. x). But, under certain circumstances, judging can become an instance of partaking. Consider, for instance, the case of Rancière's emancipated proletarians: one can suggest that, by reading the likes of Goethe and Chateaubriand, and "appropriating the "sorrows" of the idle romantic heroes...even against the will of the writers who invented these characters' (Rancière, 2011, p. 73), these workers took part in an activity that they were considered to be incapable of, namely aesthetic judgement, and in doing so, verified their equality, generating 'a shift from a given sensible world to another sensible world that defines different capacities and incapacities' (Rancière, 2011, p. 75).

My second point relates to the other central claim of the book, namely that Rancière's sentimental mode of reading and writing results in works that are simultaneously aesthetic and political. Throughout the book Panagia powerfully demonstrates the close connection between aesthetics and politics in Rancière's work, so much so that the two terms become almost indistinguishable. Rancière's Sentiments does not explore if and to what extent these terms remain distinct in Rancière's account. The question of what constitutes the difference between aesthetics and politics, however, attains a crucial significance in light of Rancière's insistence that works of theory, like literary works, are 'nothing but words' (Rancière, 2011, p. 22), which may or may not have a political effect. Such works, Rancière suggests, 'can rework the frame of our perceptions and the dynamism of our affects'; they may also 'open up new passages towards new forms of political subjectivation' (Rancière, 2011, p. 82). Whether or not they will do so, however, remains an open question, due to the 'aesthetic cut that separates outcomes from intentions and precludes any direct path towards an "other side" of words and images' (Rancière, 2011, p. 82). One cannot help but wonder if Panagia's thought-provoking exploration of the relationship between aesthetics and politics, and his already nuanced and multifaceted reading of Rancière, could have gained yet another layer with the addition of a discussion of what that aesthetic cut might mean for Rancière's sentimental mode of reading and writing. What remains clear is that Rancière's Sentiments is a must-read for anyone who is interested in the intricate relationship between aesthetics and politics in Rancière's thought. 


\section{References}

Rancière, J. 2011. The Emancipated Spectator, trans. G. Elliott. New York: Verso.

Rancière, J. 2014. Aisthesis: Scenes from the Aesthetic Regime of Art, trans. Z. Paul. New York: Verso.

Çiğdem Çıdam

Union College, Schenectady, NY 12308, USA

cidamc@union.edu 